\title{
Corporate Strategy and Tactics of SF Express in Domestic and International Courier Market
}

\author{
Simon S.M. Yuen, Ph.D. \\ College of Professional and Continuing Education \\ The Hong Kong Polytechnic University \\ JohnS.C. Yu \\ School of Business \\ Shanghai University of Finance and Economics
}

\begin{abstract}
SF express, a newly developed business giant which enjoy the largest commercial courier and express market in mainland as she grasps the golden chance to expand her business operations since early 90 's. In this paper, an overview of mainland express market development and changes are discussed. Also, a case analysis and in-depth interview were made to identify and evaluate the corporate strategy and business tactics of SF Express in local and International Courier Market.
\end{abstract}

Keywords: SF Express, Courier, Express Service, China.

\section{Introduction}

In 2017, the total number of parcel moved within China exceeded 40 billion, which is equivalent to 100 million packages per day. The number is 5 times during "Singles' Day", which was driven by promotion of Alibaba and JD.com during the whole November. The Gross Merchandise Value (GMV) of "11-11" (Double Eleven) campaign reached RMB168.2 million (USD25.3 billion) and the campaign alone generated 800 million packages which hit record-high ever.

It is not surprising that China is the strongest developing market in the Asia-Pacific express and parcels delivery sectorshowing continuous growth close to 30 percent on average per year (Niehues, et al., 2007). The Chinese express market has already become a major business growth for global players (e.g. FedEx, DHL, UPS, etc.).

China's modern express delivery service was, for a long period of time, provided in the form of express mail service by China Post Administration. It was not until the service grew to a certain scale that business entities of other nature started to emerge. In the mid to late 1980s, UPS, FedEx and DHL started to establish joint venture international cargo transportation companies with Sinotrans Group to operate the international express delivery service in China. Following China's official entry into WTO, UPS and FedEx set up wholly-owned subsidiaries in China successively to carry out the express delivery business in China since 2005. In 2007, TNT started its own operation in China through acquiring a Chinese company. (Deloitte report, 2014)

Recently, the private enterprises like SF Express, STO Express and Yunda Express emerged in the regions with developed private economy such as the Yangtze River Delta and Pearl River Delta by delivering business documents and small parcels at a lower service fee in the service form of "door-to-door, desk-to-desk" delivered within the committed time. By providing such a differentiated service from the express mail delivery service offered by the post administration, these private enterprises quickly rose to transform China's market from "dominance by one big player" to "participation of numerous players". (Deloitte report, 2014)

In this paper, an overview of mainland express market development and changes are discussed. Also, a case analysis and in-depth interview were made to identify and evaluate the corporate strategy and business tactics of SF Express in local and International Courier Market.

\section{Overview of international and local courier express business}

\subsection{International airfreight and express business}

In general, the two primary distribution channels are via forwarders and integrated carriers in international airfreight and express market. (Figure 2.1 and 2.2) 
Figure 2.1: Distribution channel via forwarders

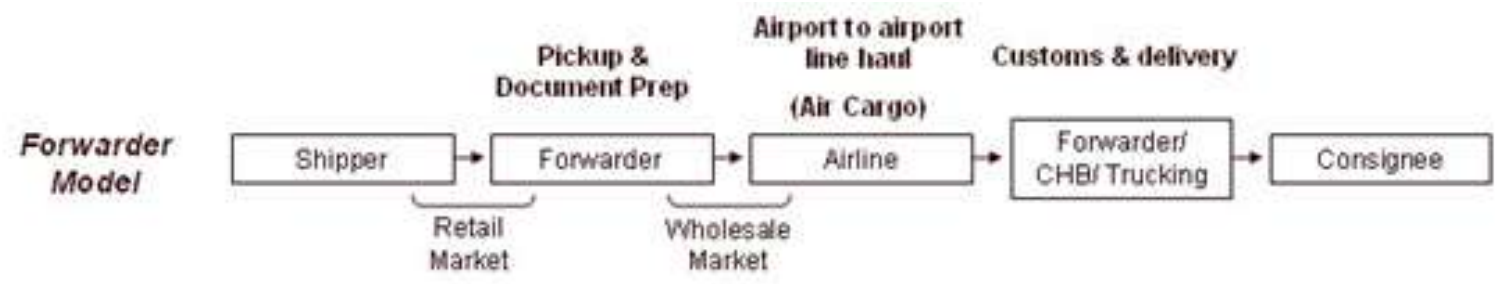

Ex UPS SC8, DHL Danzas, Expeditors, Nippon Express, K\&N, etc.

Figure 2.2: Distribution channel via integrated carriers

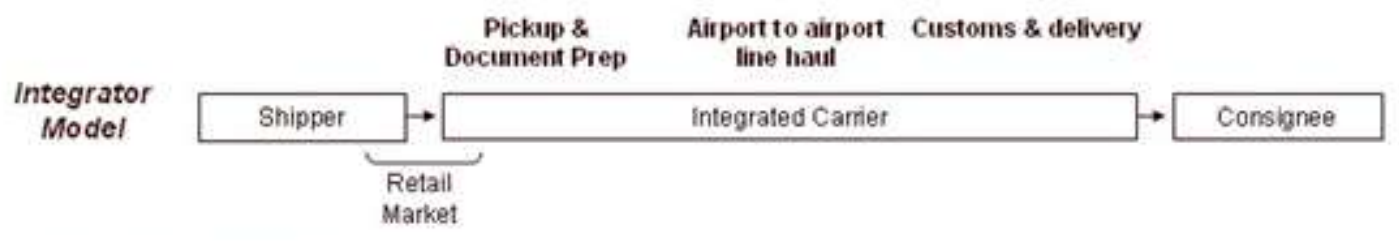

Ex. UPS, FedEx, DHL and TNT

The main difference between forwarder model and integrator model is the gap of so-call "wholesale market" (Morrell, 2011). The existence of this market allows freight forwarder to reap a benefit from getting discount from airline on bulk purchase, handling clearance and documentation on behalf of consignee as well as providing airport-to-door trucking services. (Table 2.1)

Table 2.1: Difference between forwarder model and integrator model

\begin{tabular}{|l|l|l|l|}
\hline Charges/Model & $\begin{array}{l}\text { Documentation fee } \\
\text { and customs fee }\end{array}$ & Airfreight cost & Delivery charges \\
\hline Forwarder model & Paid by customer & $\begin{array}{l}\text { Major profit via } \\
\text { consolidation }\end{array}$ & Upon request \\
\hline Integrator model & Included in total charge \\
\hline
\end{tabular}

\subsection{Domestic express market in Mainland China}

China Post normally is monopoly in the domestic express delivery market over decades, but has been losing significant market share since then. Although China Post is still the strongest player at the moment, it continuously loses ground to fast growing domestic private competitors.

With the final opening of the express market in 2005, China Post's remaining "safe" income stream is the sole player on delivery of personal mail letters. China Post is trying to lobby for new regulation, for example, to ban all express companies in China (other than EMS) from delivering goods that weigh less than 350 grams, but these efforts face pressure from competitors as well as the State Council. (Niehues, et al., 2007)

In Year 2015, with the rapid growth of China express market, many new operators came into new domestic express players. Over thousands of small to medium-sized companies, the vast majorities are local truckers who operate at very low prices and varying (mostly low standard) service levels in the fragmented geographical and regulatory landscape of Chinese logistics operations. The strong protectionism of local authorities, especially with regard to road transport, put up significant barriers to large expansion strategies (Pechet, 2010). Some local operators, such as STO Express (申通快 遞), YTO Express (圓通速遞), however, have found ways to expand profitably (i.e. double digit growth of business in last decade). Nonetheless, none of the new emerging local operators captured more than 10 percent of the market, leaving all the players except China Post in very fragmented positions (Yang \& Wang, 2011).

Apart from internal competition among those domestic express companies, some of the e-commerce giants like Alibaba and JD.com either invested in some traditional express companies or set up its own logistics arm in order to enter the high-growing market. For example, Alibaba set up Cainiao Network Technology Co. Ltd., together with SF Express, STO Express and YTO Express, which provides a data platform to integrate existing industry logistics resources and empowers connected partners with data products and services. 
The platform drives efficiency in China's logistics industry by connecting e-commerce companies with players along the logistics chain to enable end-to-end solutions. Its goal is to realize delivery anywhere in China within 24 hours, and across the globe within 72 hours (Alibaba, 2018).

On the other hand, JD.com set up in logistics arm - JD Logistics, as a stand-alone subsidiary to support logistics services to JD.com, which is one of the largest e-retailers in China by revenue (Net revenues for the full year of 2017 were RMB362.3 billion (US\$55.7 billion), an increase of $40.3 \%$ from the full year of 2016). As of September 2017, JD.com operated 7 fulfillment centers and 405 warehouses covering 2,830 counties and districts across China, staffed by its own employees (JD.com, 2018).

\section{S.F. Express: The Development}

S.F. Express Holdings, SF (Stock code: 002352.SZ) established its operations in ShunDe (a small village close to Guangzhou and Shenzhen) in 1993 and pioneered door to door express deliveries across the China-HK border. It was found with 6-men providing sample and document delivery service between Guangdong Province and Hong Kong Over the past 25 years, SF has earned a well-deserved reputation for highly reliable and efficient express service in Greater China (SF Express, 2017a). SF's coverage in Greater China is second to none within the express industry. This geographic landscape will be further enhanced by commitment to continue investing and expanding in more lucrative international markets (e.g. America, Europe, Middle East, Africa etc.).

Listed and headquartered in Shenzhen, SF has established an extensive global networkof business units that specialize in a wide range of services, including express delivery, online shopping platform (SF Best), logistics, supply chain, fulfillment, heavyweight, warehousing, cold chain, financial service, insurance etc., in various sectors including auto parts, health food, fashion, electronic products etc.

\section{Table 3.1: General information and Quick checklist of S.F. Holdings} (SF Express, 2017a, 2017b)

\begin{tabular}{|c|c|}
\hline $\begin{array}{l}\text { Key Shareholders and } \\
\text { Revenue }\end{array}$ & $\begin{array}{l}\text { Wong Wei (Dick), China Merchants Group and CITIC Capital. } \\
\text { Revenue in 2017: RMB71.09 Billion } \\
\text { No. of packages: } 335 \text { million in } 2017\end{array}$ \\
\hline Network Coverage & $\begin{array}{l}\text { 13,000+ service stations / points and 35,000+ lockers (managed by Hive Box) } \\
\text { within Mainland China } \\
\text { Strong presence in Mainland China, covering } 23 \text { provinces, } 4 \text { municipality cities, } \\
5 \text { autonomous regions, and } 2 \text { special administrative regions } \\
\text { North Asia (Japan, South Korea, Taiwan, Mongolia) } \\
\text { South Asia (Singapore, Malaysia, Vietnam, Indonesia, Thailand, Cambodia, } \\
\text { India, Pakistan, Bangladesh, Sri Lanka, Brunei, Myanmar, Philippines, Pakistan) } \\
\text { Oceania (Australia, New Zealand) } \\
\text { America (USA, Brazil, Canada, Mexico, Chile) } \\
\text { Russia } \\
\text { Middle East (UAE) } \\
\text { EU-28 and UK }\end{array}$ \\
\hline Service Coverage & $\begin{array}{l}\text { Express Delivery, (international, domestic inter-city and intra-city), Cold Chain, } \\
\text { Supply Chain, Online Shopping Platform (SF Best), Heavyweight, Finance, } \\
\text { Takeaway Delivery, Mobile Fixing, Lottery etc. }\end{array}$ \\
\hline $\begin{array}{l}\text { Transit time (Express } \\
\text { Product) }\end{array}$ & $\begin{array}{l}\text { Same day delivery for intra-city service in China } \\
1 \text { day working day for inter-province in China } \\
\text { 3-7 working days transit time for international service }\end{array}$ \\
\hline Operation type & $\begin{array}{l}\text { SFbuilds and runs its operating networks in Greater China without third party } \\
\text { involvement } \\
\text { International operations include a mix of self-operate and virtual service station } \\
\text { (VSS), which includes outsourcing delivery and pickup to local agents, with } \\
\text { supervision by own staff. }\end{array}$ \\
\hline No. Of Employees & $350,000+($ No. of courier: $210,000+)$ \\
\hline $\begin{array}{l}\text { Sorting \& Distribution, and } \\
\text { Customer Services Facilities }\end{array}$ & $\begin{array}{l}\text { SF has } 10 \text { hub-level transshipment stations, } 39 \text { aviation and railway transit } \\
\text { points, } 172 \text { fully fledged distribution hubs and } 113 \text { standard distribution hubs, } \\
\text { some of which have fully automated and efficient sorting systems to guarantee }\end{array}$ \\
\hline
\end{tabular}




\begin{tabular}{|c|c|}
\hline & $\begin{array}{l}\text { timely and secure delivery of shipments. } \\
\text { SF also has } 9 \text { independent call centers with } 7140 \text { customer service } \\
\text { representatives serving } 1.15 \text { million customers every day. }\end{array}$ \\
\hline Fleet Capacity & $\begin{array}{l}57 \text { cargo freighters ( } 41 \text { are wholly owned) } \sim \text { carried } 488,000 \text { tons in } 2017 \\
1,700+\text { of passenger and cargo flights capacity } \sim \text { carried } 621,000 \text { tons in } 2017 \\
16,000+\text { vehicles (own) and } 13,000+\text { vehicles (outsourced) }\end{array}$ \\
\hline
\end{tabular}

\section{Research Method}

In order to provide an in-depth review and analysis on courier and express business in mainland China, a comprehensive literature review of related documents and reports from government, industrial \& professional associations as well as academic \& scholarly journals were made. Also, other sources like newspapers, commercial magazines, company webpages and internet materials were reviewed.

Besides, personal interviews with senior management (former) of SF express and practitioners were conducted. They are being selected because top management plays a critical role in a company's operation and give overall company directions. They are the ones who identify and evaluate business strategies, tactics and practices of courier and express services in mainland China.

\section{Corporate strategy and tactics of SF Express}

\subsection{Staying at cutting-edge on technology}

SF builds its success on advanced technology. Currently, it has a team of 3,600+ R\&D staff. To enhance customer satisfaction through quality services, SF invested heavily in building a powerful information system. SF continued to improve end-to-end express delivery procedures that span monitoring, tracking, inquiry and resource allocation. For example, a new ERP system was fully implemented in 2016 under "Phoenix Project", which integrates Accounting, CRM, Line-haul, and Network Planning systems into a single platform.

More importantly, with the support application of WeChat (mobile app) and SF Pay, customer can place order, set preferred delivery time, track shipment status, and appraise service quality of courier, and settle payment with user friendly interface easily. To SF, it can collect and analyze such "Big Data" from customers' preference in order to formulate strategies and utilize resources.

SF Pay, for example, is a mobile app more than mere customer convenience. Through the app, SF can also introduce financial products such as investment and products with return higher than deposit. Besides, the app can also be able to do location-based marketing when customers use or open the app. Ashley Law, COO and CFO of SF Financial Services Business Group, said using location-based data, SF can compile target profiles in areas where it can reach its clients to introduce its financial products.

\subsection{Elevating management practices into methodologies}

Through years of efforts to improve management, strengthen communication, increase productivity, and streamline the chain of command, SF developed a set of distinctive, well-balanced management methodologies geared to the express delivery sector that cover business operation, product lifecycle and strategic plan. These methodologies are in the following areas:

- Making decisions in response to complex conditions (e.g. China express market is evolving with the growth of B2C business and price competition is keen as well. What SF differentiates from others is the service quality including competitive transit time, low loss and damage rates and innovative ways of last mile delivery.)

- Balancing growth and quality (e.g. Unlike other express companies in China, SF is operating on its own without franchising. It could help achieve quality service as all operations are standardized and monitored by headquarter.)

- Identifying a clearly-defined business strategy based on massive data and then ever-changing situation (e.g. With the support of Asura and ERP system, SF is able to analyze shipping pattern of customer and the outcome could help the management to make decision in resources planning)

- Sustaining steady and healthy development (e.g. SF Charity Foundation supported building primary school in poverty towns and helping victims in natural disaster.)

Vision: Becoming the most dependable and respected express delivery service provider.

Mission: SF Express is committed to:

- Providing our employees with a fulfilling job. 
- Delivering items swiftly, safely and accurately as required by customers

- Staying in the vanguard of the express delivery sector

- Undertaking more social responsibility as we grow

\subsection{Dedicated Cargo Hub}

Approved by China government, SF has started to build its new country-wide mega hub in Ezhou (鄂州), Hubei (湖北). SF will invest 2.3 billion yuan (US\$348 million) to build Asia's first professional cargo airport. The provincial government and an investment company in Shenzhen also invested 2.45 billion yuan and 250 million yuan respectively, bringing the total registered capital of the new airport to 5 billion yuan. The airport, customized for SF, which owns a 46 percent stake, is positioned as a hub cargo airport and a regional airport for passenger transportation.

According to SF, the airport, which will serve as an important national transfer station for cargo deliveries, is estimated to reach a cargo throughput of 2.452 million metric tons and receive 1 million passengers by 2025 . SF will also develop a logistics park near the airport, providing delivery, airplane repair and maintenance, and airline services.

Figure 5.1 SF Airline

Sources: SF Express

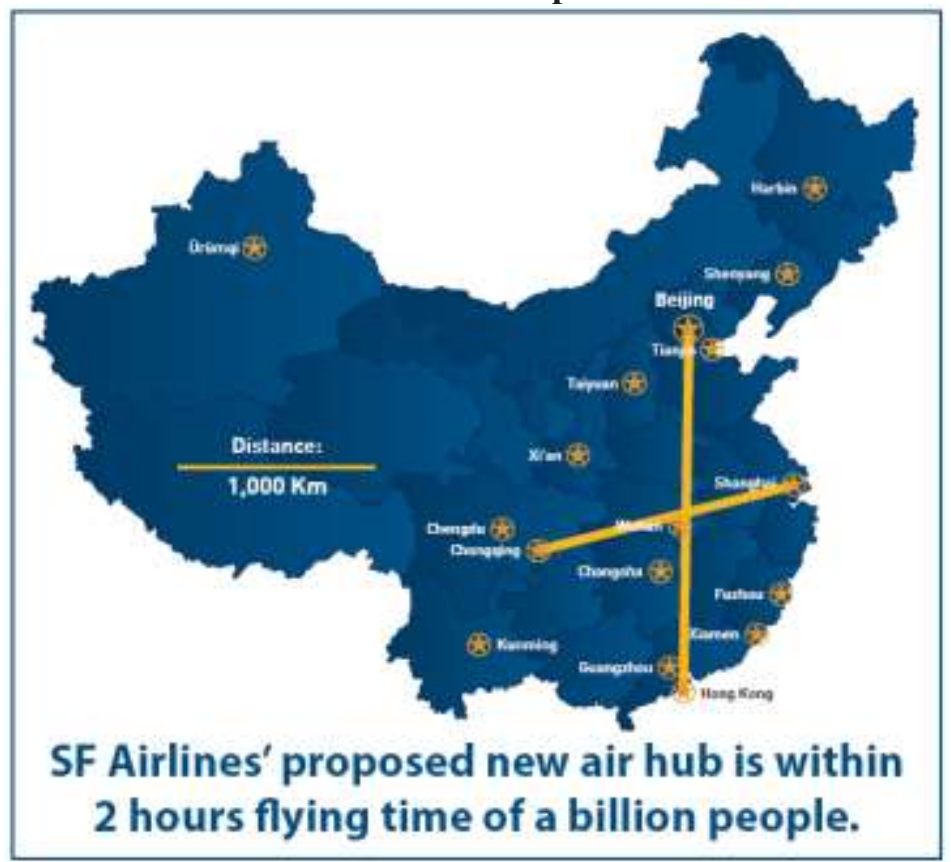

\subsection{JV with UPS}

On 28 September 2017, UPS and SF Holdings JV received regulatory approval in China.JV combines SF's extensive 13,000 service points across 331 cities in China with UPS' globally integrated 220 country network in world's fastest growing small package market.

It is expected that both the express delivery giants will leverage their complementary networks, service portfolios, technologies and logistics expertise, to provide customers with greater coverage, additional routing options, increased capacity, and more choice in transit times and service options. The joint venture will initially focus on supporting these highly competitive joint service offerings on the China-to-US lane, with planned expansion to markets in the rest of the world (Air Cargo World, 2017).

To SF, it provides an opportunity to enjoy more options of line-haul and better delivery service to US and other overseas cities, by utilizing the freighters, infrastructure and sophisticated operations team of UPS. Likewise, UPS can also benefit from SF's strong delivery network and domestic coverage in China. It seems it could be a "win-win" scenario in operational perspective. Commercially, the risk of leakage of customers' shipping information to other and competition of selling services could be a hindrance of the collaboration and alignment. The objective of bring competitive advantages to customers in China and around the world remains challenging and doubtful. 


\subsection{Product differentiation}

Though SF has differentiated its products in international services, the transit time between different products are not definite. The key reason is SF has limited autonomy in line-haul from China to overseas destinations. As SF has launched some scheduled charters from China to international markets (e.g. Osaka - Nanjing, Changsha - Ho Chi Minh city etc.), it is the right time to re-define its products with more definite transit time and clearance standard, by benchmarking FedEx or UPS.

For example, for international products in FedEx, there are International Priority (IP), International Deferred (IE), International Priority Freight (IPF), International Deferred Freight (IEF), International Express Freight (IXF), Airport-toAirport (ATA) etc. (FedEx, 2016; Ryu, et al., 2014) The differences of these products are summarized below (Table 5.1):

Table 5.1: Summary of different international products in FedEx

\begin{tabular}{|l|c|c|c|c|c|c|}
\hline & IP & IE & IPF & IEF & IXF & ATA \\
\hline Package & $\sqrt{ }$ & $\sqrt{ }$ & & & & \\
\hline Freight (Weight $>68 \mathrm{~kg})$ & & & $\sqrt{ }$ & $\sqrt{ }$ & $\sqrt{ }$ & $\sqrt{ }$ \\
\hline Pick up/delivery by courier & $\sqrt{ }$ & $\sqrt{ }$ & $\sqrt{ }$ & $\sqrt{ }$ & & \\
\hline Money Back Guarantee & $\sqrt{ }$ & $\sqrt{ }$ & $\sqrt{ }$ & $\sqrt{ }$ & & \\
\hline Transit time commitment & $\begin{array}{c}\text { Pick up + 1 } \\
\text { day }\end{array}$ & $\begin{array}{c}\text { Pick up + } \\
\text { 2days }\end{array}$ & $\begin{array}{c}\text { Pick up + } \\
2 \text { day }\end{array}$ & $\begin{array}{c}\text { Pick up + 3 } \\
\text { days }\end{array}$ & $\begin{array}{c}21 \\
\text { days }\end{array}$ & $\begin{array}{c}\text { No } \\
\text { commitment }\end{array}$ \\
\hline
\end{tabular}

\subsection{Expand through acquisition}

Building self-owned business unit and service center not only takes time to develop, but also increase risk in entering market, which require relatively large capital investment, time to build up customer loyalty as well as local expertise. To speed up the expansion, SF may consider acquiring local and oversea (i.e. medium size) express players in niche market or geographical areas; and developing its own operation few years after the acquisition.

\subsection{Promote SF brand}

Being a famous brand in China, SF is not high recognized in overseas and international express delivery market. Compared with market leader, customer is not familiarized with SF on safe and speedy services. It is suggested that SF launch a country-wide marketing campaign and build up reputation aligned with SF's core value - "FIRST" which denotes Faint, Integrity, Responsibility, Service and Team, Corporate Governance and Corporate Social Responsibility. Other ways include publicity in US and Hong Kong market, alliance and provision of more innovative services.

\subsection{Develop e-retailing platform}

Recently, SF launched an e-retailing platform - INTMALL (www.intmall.com), which target to sell products directly to customers in Russia, providing a one-stop shop logistics and delivery services. This is the same model as SFBest, which is a platform to China customers, selling grocery, food, childcare products online, with delivery service backed by SF.

\section{Analysis and Implications}

\subsection{SWOT Analysis and Major findings}

With a mysterious and tremendous success of SF, a number of researchers and professionals have been trying to put effort on producing SWOT analysis of SF. Liu and Kang (2015) used SWOT and other analytical methods to define the superiorities, weaknesses, challenges, threats and proposed relevant strategies and referential suggestions for SF's operational models. While Kong (2014) has tried to align the SWOT of SF with its strategy of entering into Brazilian market.

In this section, we are summarizing the SWOT of SF Express, especially for its international penetration as below (Table $6.1)$. 
Table 6.1 SWOT of SF Express

\begin{tabular}{|c|c|c|c|}
\hline Strength & Weakness & Threat & Opportunity \\
\hline $\begin{array}{l}\text { Strong coverage and } \\
\text { high service quality } \\
\text { in China }\end{array}$ & $\begin{array}{l}\text { Weak clearance and } \\
\text { delivery capability in } \\
\text { overseas market }\end{array}$ & $\begin{array}{l}\text { Competition from } \\
\text { domestic players, i.e. } \\
\text { YTO Express acquired } \\
\text { HK listed On Time } \\
\text { Logistics to expand int'l } \\
\text { coverage }\end{array}$ & $\begin{array}{l}\text { The outbound and } \\
\text { inbound volume is } \\
\text { growing thanks to } \\
\text { overwhelming volume } \\
\text { growth from cross } \\
\text { border e-commerce }\end{array}$ \\
\hline $\begin{array}{l}\text { Direct control and } \\
\text { management model, } \\
\text { which allows SF to } \\
\text { provide premium } \\
\text { service to customers. }\end{array}$ & $\begin{array}{l}\text { High operating cost and } \\
\text { investment. }\end{array}$ & $\begin{array}{l}\text { The parcel volume } \\
\text { growth becomes flat } \\
\text { (i.e. } 20 \%+\text { ) per annum }\end{array}$ & $\begin{array}{l}\text { Target medium to high } \\
\text { end segment and avoid } \\
\text { over-reliance on low- } \\
\text { yield } \\
\text { shipment. Taobao } \\
\end{array}$ \\
\hline $\begin{array}{l}\text { Competitive rate for } \\
\text { international } \\
\text { business }\end{array}$ & $\begin{array}{l}\text { High operating cost in } \\
\text { Japan and United States }\end{array}$ & $\begin{array}{l}\text { Alibaba's Cainiao } \\
\text { Network is providing } \\
\text { economy postal solution } \\
\text { (by investing in } \\
\text { Singapore Post) }\end{array}$ & $\begin{array}{l}\text { The operating cost } \\
\text { will be lowered } \\
\text { together with growing } \\
\text { volume. }\end{array}$ \\
\hline $\begin{array}{lr}\begin{array}{l}\text { Differentiation } \\
\text { products }\end{array} & \text { of } \\
\text { services } & \end{array}$ & $\begin{array}{l}\text { The speed and quality of } \\
\text { international shipments } \\
\text { are still less competitive } \\
\text { in market, when } \\
\text { compared with FedEx, } \\
\text { UPS and DHL }\end{array}$ & $\begin{array}{l}\text { DHL E-commerce is } \\
\text { attacking the market by } \\
\text { offering competitive } \\
\text { rate with high standard } \\
\text { level }\end{array}$ & $\begin{array}{l}\text { Chinese customers are } \\
\text { loyal to SF brand } \\
\text { JV with UPS to } \\
\text { expand international } \\
\text { market }\end{array}$ \\
\hline $\begin{array}{l}\text { High reputation and } \\
\text { brand awareness in } \\
\text { China market }\end{array}$ & $\begin{array}{l}\text { Low profile in overseas } \\
\text { market }\end{array}$ & $\begin{array}{l}\text { Strong marketing } \\
\text { campaign from DHL, } \\
\text { FedEx, UPS, and even } \\
\text { Alibaba } \\
\text { Network }\end{array}$ & 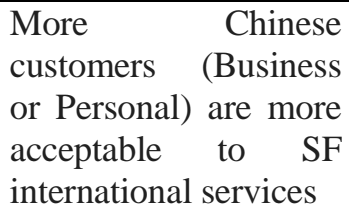 \\
\hline
\end{tabular}

Also, major findings about the strengths, challenges and future business direction of SF Express are shown in appendix I.

\section{Conclusion}

Given the opportunities of exporting China-made products to global market as well as huge demand of China domestic import market, SF should grasp the golden chance to expand its operation from China domestic express delivery service to international express delivery service. It not only offers customers an option to ship from/to China, also diversify business mix and seek for an alternative to robust business growth after 20 years of establishment in China.

As per founder of SF - Mr. Dick Wang, SF is not targeting a market size RMB400 billion express delivery market, but a RMB1.2trillion logistics market in China. Diversification will definitely the key strategy to SF in foreseeable future. However, the transformation from a traditional delivery company to e-commerce and total logistics solutions is not an as straightforward as Dick can imagine. Zhu and Lane (2015) detailed the planning and actions carried out by SF from 2012, from setting up SF Best to opening Heike Store (SF Convenience store) in 2014. Heike Store turned out to be doomed and SF lost RMB3 billion in this $\mathrm{O} 2 \mathrm{O}$ project. However, such "experiment" will not stop the Dick's ambition of leading SF to be a total logistics solution provider in China and over the world.

Opportunistic though it seems, there is still a long way to expand international express delivery service which is challenged by lack of local expertise, customer base, limited service area/level, reputation and recognition in overseas market. Yet, management support of SF is vital for global expansion as it is expected that the injection of investment should be huge with long payback period.

With prime competition ahead, SF should have dynamic and proactive approach to provide and "create" new business strategy and tactics and maintaining her sustainable growth, as a "flying dragon". 


\section{References}

Air Cargo World. (2017). UPS, SF Holding joint venture wins regulatory approval in China. Air Cargo World, Retrieved from https://aircargoworld.com/allposts/ups-sf-holding-joint-venture-wins-regulatory-approval-inchina/

Alibaba. (2018). About Alibaba.com. Retrieved from https://www.alibaba.com/

Deloitte Report. (2014). Deloitte Industry Report: China's express sector development report 2014. Development \& Research Center of the State Post Bureau / Deloitte. Retrieved from https://www2.deloitte.com/content/dam/Deloitte/global/Documents/Consumer-Business/gx-cb-china-expresssector.pdf

FedEx. (2016). International express delivery, shipping and freight services. Retrieved from http://www.fedex.com/hk_english/services/wwservices.html

JD.com. (2018). About JD.com. Retrieved from http://www.jd.com/

Kong, X.L. (2014). A Chinese Company Entering into the Brazilian Market - Case Company: SF Express. Retrieved from https://www.theseus.fi/bitstream/handle/10024/79073/Kong\%20Xianglin\%20thesis\%20final.pdf?sequence=1 \&isAllowed=y

Liu, Y. \& Kang, T. (2015). Operational Model of China's Express Services Industry: A Case Study of SF-Express. Journal of International Trade and Commerce, 11(5), 43-58.

Morrell, P.S. (2011). Moving boxes by air: the economics of international air cargo. England: Ashgate Publishing Limited.

Niehues, A., Zubrod, J., \&Tse, E. (2007). Express opportunities in China: Packaging a strategy for the international and domestic express delivery market. Retrieved from http://www.boozallen.com/content/dam/boozallen/media/file/Express_Opportunities_in_China.pdf

Pechet, N. (2010). Gaining Foothold in China's Domestic Time-Sensitive Logistics Market Requires Patience, Local Know-How. Retrieved from http://www.supplychainbrain.com/content/logisticstransportation/logisticsoutsourcing/single-article-page/article/gaining-foothold-in-chinas-domestic-time-sensitive-logistics-marketrequires-patience-local-know-h/

Ryu, M., Han, M., \& Choi, S. (2014). FedEx in China. Journal of the International Academy for Case Studies, 20 (3), 87-104. Retrieved from http://www.alliedacademies.org/articles/jiacsvol20no32014.pdf\#page=97

SF Express. (2017a). SF company profile. Retrieved from http://www.sf-express.com/cn/en/about_us/about_sf/company_introduction/

SF Express. (2017b). SF development history. Retrieved from http://www.sf-express.com/cn/en/about_us/about_sf/development_history/

Yang, Y., \& Wang, D. (2011). Study on the solutions for the development of private express companies. Forecasting, 30 (2), 71-76. Retrieved from http://cf.lcchina.org.cn/docbak/2/1/b/422808_523902486a21b.pdf

Appendix I: Summary of SF's markets and their strengths, challenges and future business direction

Major finding and analysis of SF Express

\begin{tabular}{|l|l|l|l|l|}
\hline Market & $\begin{array}{l}\text { Existing } \\
\text { business focus }\end{array}$ & $\begin{array}{l}\text { Strengths of existing } \\
\text { business }\end{array}$ & $\begin{array}{l}\text { Challenges of existing } \\
\text { business }\end{array}$ & $\begin{array}{l}\text { Future business } \\
\text { direction }\end{array}$ \\
\hline $\begin{array}{l}\text { China } \\
\text { domestic }\end{array}$ & $\begin{array}{l}\text { Intra-city, intra- } \\
\text { province, inter- } \\
\text { province } \\
\text { express delivery } \\
\text { service }\end{array}$ & $\begin{array}{l}\text { 51+ charter flights daily } \\
\text { Strong geographical } \\
\text { coverage } \\
\text { Self-owned and } \\
\text { operated services } \\
\text { Premium service in } \\
\text { terms of speed, low lost } \\
\text { and damage rate etc. } \\
\text { Customer loyalty } \\
\text { Reputable brand }\end{array}$ & $\begin{array}{l}\text { Surging operational cost } \\
\text { (labor, fuel cost etc.) } \\
\text { Growth of parcel volume } \\
\text { is down from 50\% to } \\
\text { 20\%+ per annum } \\
\text { Rate increase to provide } \\
\text { quality service fierce } \\
\text { Competition from 3 big } \\
\text { players and domestic } \\
\text { competitors. }\end{array}$ & $\begin{array}{l}\text { Commodity-specific 3PL } \\
\text { services (cold chain, red } \\
\text { wine, textile, electronics) } \\
\text { IT-centric, transform } \\
\text { from a logistics company } \\
\text { into an IT company } \\
\text { B2C delivery service by } \\
\text { means of low cost } \\
\text { options (e.g. Hive Box) } \\
\text { Own cargo hub in } \\
\text { E'Zhou, Hubei } \\
\text { Diversify business scope, }\end{array}$ \\
\hline
\end{tabular}




\begin{tabular}{|c|c|c|c|c|}
\hline & & & & $\begin{array}{l}\text { from traditional express } \\
\text { delivery to total logistics } \\
\text { and finance solution } \\
\text { provider } \\
\text { JV with Havi for Cold } \\
\text { Chain Business }\end{array}$ \\
\hline $\begin{array}{l}\text { Intra-Asia } \\
\text { (HK, TW, SG. } \\
\text { MY) }\end{array}$ & $\begin{array}{l}\text { Expanding } \\
\text { service country } \\
\text { and area } \\
\text { Enhancing } \\
\text { country-wide } \\
\text { total transit time }\end{array}$ & $\begin{array}{l}\text { Competitive price } \\
\text { Relatively shorter } \\
\text { transit time for China } \\
\text { inbound (esp. South } \\
\text { China) } \\
\text { Potential customer in } \\
\text { China }\end{array}$ & $\begin{array}{l}\text { Small shipment volume at } \\
\text { debut stage } \\
\text { Not well known by } \\
\text { overseas shipper/customer }\end{array}$ & $\begin{array}{l}\text { Enhance China inbound } \\
\text { and outbound shipment } \\
\text { volume } \\
\text { Promote brand } \\
\text { awareness } \\
\text { Operate own aircrafts to } \\
\text { improve service quality } \\
\text { Grasp the opportunities } \\
\text { of Belt and Road } \\
\text { Initiative. }\end{array}$ \\
\hline International & $\begin{array}{l}\text { Adopt Virtual } \\
\text { Service Station } \\
\text { (VSS) mode } \\
\text { Utilize Postal } \\
\text { channel for e- } \\
\text { parcel product }\end{array}$ & $\begin{array}{l}\text { Competitive price } \\
\text { Relatively shorter } \\
\text { transit time for China } \\
\text { inbound (esp. South } \\
\text { China) } \\
\text { Potential customer in } \\
\text { China and Chinese } \\
\text { customers overseas }\end{array}$ & $\begin{array}{l}\text { Small shipment volume at } \\
\text { debut stage } \\
\text { Not well known by } \\
\text { overseas shipper/customer } \\
\text { Long total transit time } \\
\text { Rely on agent for intra- } \\
\text { country delivery in } \\
\text { overseas markets }\end{array}$ & $\begin{array}{l}\text { Enhance China inbound } \\
\text { and outbound shipment } \\
\text { volume } \\
\text { Improve total transit time } \\
\text { Promote brand } \\
\text { awareness } \\
\text { Provide total logistics } \\
\text { solutions from pickup, } \\
\text { clearance, delivery and } \\
\text { even collaborate on e- } \\
\text { retailing platform (e.g. } \\
\text { Intmall.com) } \\
\text { JV with UPS }\end{array}$ \\
\hline
\end{tabular}

